\title{
Utilization of Essential Oils and Chemical Substance against Varroa Mite, Varroa destructor Anderson and Trueman on Two Stocks of Apis mellifera lamerkii in Egypt
}

\author{
M. F. Hassan", Sally F. Allam*, Margaret A. Rizk ${ }^{* *}$ and A.Y. Zaki** \\ "Department of Zoology and Agriculture Nematology, Fac. of Agric., Cairo Univ. \\ ***ant Protection Research Institute, Agric. Res. Center, Min. of Agric.
}

\begin{abstract}
During September-November 2006 in Giza Governorate mint oil, chamomile oil, neem oil and mixture of (neem, black cumin and jasmine oils) compared with the chemical substance mavrik were tested for their efficacy in controlling the bee mite Varroa destructor on two stocks of Apis mellifera lamerkii. The efficacy rate in Egyptian race was $44.76 \%$, $66.64 \%, 4.95 \%, 52.88 \%$ and $89.54 \%$, respectively, while in hybrid Egyptian carniolan was 64.75\%, 41.08\%, 61.7\%, $59.49 \%$ and $78.78 \%$, respectively. This study indicates that neem oil is not suitable against Egyptian race, genetic control by using the local Egyptian race Apis mellifera lamerckii and the cross-breeding between two geographical races resulting hybrid vigor could be an effective and reliable method for the control of Varroa destructor. Using mint oil and mixture of oils were also more suitable with cotton strips. Finally, the importance of cultivation of aromatic and medicinal plants around apiaries, as a cultural control, was recommended in IPM programmes to control Varroa mite.
\end{abstract}

Key Words: Varroa destructor, control, essential oils, mavrik, biopesticide agent, cultural control, genetic improvement, Apis mellifera lamerkii.

\section{INTRODUCTION}

Recently, the beekeeping industry in Egypt has been confronted with serious disease named "Varroasis" which is caused by the ecto-parasitic mite, Varroa Jacobsoni Oudemans. This mite parasitizing Apis mellifera feeds on haemolymph of broods, drones and workers, causing serious damage to hives, decrease in broods and emerging bees, deforming bees and weaking in colonies ability to pollinate plants and produce honey (De Jong et al., 1982). Finally, it leads to the death of colonies or migration of queen and worker bees.

Varroa jacobsoni Oud. was recorded for the first time in Egypt in 1983 (Wienands, 1988), and within the last few years the parasite has become a subject of concern to beekeepers and has been found in the majority of the Egyptian Governorates causing economic losses due to destroy of many apiaries (Abd El-Fattah et al.,1991). According to Anderson and Trueman (2000) Varroa in Egypt is Varroa destructor (Korea haplotype). The control of Varroa mite is especially difficult because the majorities of individuals live inside the sealed brood for reproduction and thus well protected from different methods of control (Hoppe et al., 1989). Acaricides appeared effective but its application within the hive contaminates the honey and wax, moreover the mites may develop resistance against these chemicals (Ifantidis, 1987). In contrast, other workers used the essential oils to control this pest (Fathy and Fouly, 1993, El-Shemy, 1997 and Allam et al., 2003). Cross breeding between two geographical races especially with Egyptian race $A$. mellifera lamarckii was very important for future bees to tolerate diseases and help for difference in genetic structure in hybrids (Abo-Shady, 1939). Guzman et al. (1996) found that the European, Africanized and hybrid honeybees differ in susceptibility to Varroa infestation and if Varroa differentially reproduce on different types of brood. They added that European brood was twice as attractive to female Varroa compared to Africanized brood. Bienefeld (1996) reported that reducing the duration of the length of the capped brood phase is considered to be a good approach for breeding honeybees resistant to $V$. Jacobsoni. Allam et al. (1999) found that Hybrid stock from the Egyptian mother was most susceptible. The tolerance of stock has been attributed to cleaning movements, shorter post capping period, the durations of all biological aspects and behaviour. Therefore, this work was carried out to evaluate the efficiency of some essential oils of mint, chamomile, neem, black cumin and jasmine compared with chemical pesticide (Mavrik) to manage the Varroa mite on two stocks of A. mellifera lamerkii.

\section{MATERIALS AND METHODS}

Experiments were carried out during the fall (September-November 2006) in Giza Governorate (Kerdasa region).

\section{Preparation of the colonies from the two stocks:}

Thirty six naturally infested honeybee colonies nearly similar in their strength. Eighteen colonies 
were headed by Egyptian queens A. mellifera lamerkii (L.H.) (local race) (Cockerell, $1906 \mathrm{a}, \mathrm{b}, \mathrm{c}$ ). The mated queens from this race were brought from Manfalot province; Assiut Governorate and were introduced to the unqueened colonies of A. mellifera carnica and the other eighteen colonies were headed by hybrid Egyptian queens (Apis mellifera lamerkii) mated with hybrid carniolan drones (A.m. carnica with no Egyptian drone, (C.H.) (Allam et.al.1999). The colonies were divided into 12 groups; 6 C.H. and 6 L.H. Each group contained 3 colonies as replicates for each treatment out of the five tested materials and the last 3 colonies were used as control.

\section{Tested materials:}

1- Common spearmint oil (Mentha spicata, Labiatae).

2- Chamomile oil (Matricaria chamomilla, Compositae).

3- Neem oil (Azadirachta indica, Mmelioidae).

4- Black cumin oil (Nigella stativa, Umbellifereae) extract of seeds.

5- Jasmine oil (Jasmine grandiflorum, Oleaceae) extract of flowers.

6- Mavrik (22.3\% fluvalinate) (Mavrik aquaflow Novartis).

\section{Preparing essential oils and mixture:}

Prepared by mixing $15 \mathrm{ml}$ oil with $0.5 \mathrm{ml}$ Triton$\mathrm{x}$ (emulsifier) and sufficient water.

1- Mint oil with water to obtain $100 \mathrm{ml}$ of solution.

2- Chamomile oil was prepared by mixing $15 \mathrm{ml}$ oil with $0.5 \mathrm{ml}$ Triton-x (emulsifier) and sufficient water to obtain $100 \mathrm{ml}$ of solution.

3- Neem oil was prepared by mixing $15 \mathrm{ml}$ oil with sufficient water to obtain $100 \mathrm{ml}$ of solution.

4- Mavrik (15\%) was prepared by mixing $65 \mathrm{ml}$ of mavrik and water to obtain $100 \mathrm{ml}$ of solution.

5- The mixture was $5 \mathrm{ml}$ neem oil, $5 \mathrm{ml}$ black cumim oil and $5 \mathrm{ml}$ jasmine oil with water added to obtain $100 \mathrm{ml}$ of solution.

\section{Experimental procedures:}

All colonies were treated with strips of cotton material $(20 \times 2.5 \mathrm{~cm} \times 5 \mathrm{~mm})$ saturated with oil $(10-15$ $\mathrm{ml}$ ) from solution. One strip was hanged between the middle combs every week in all treatments for 10 weeks.

\section{Assessment of the efficacy levels:}

The infestation levels in all experiment colonies were determined before and after each application. The following data were recorded:

1- Number of dead mites fallen down on a white card board (coated with vaseline) located under the colony.

2- Number of mites in random sample of approximately 100 alive bees.

$3-.$. Number of mites in 10 cells of each worker and drone brood (if available) or in 20 workers cells if drone brood was not available.

4-The area of sealed worker brood (colony strength).

The efficacy of the tested substance was calculated after each application according to the equation of Girdani and Leporati (1989):

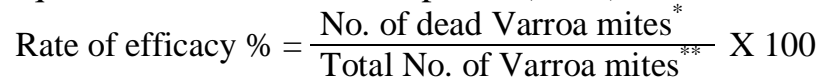

"Dropped mites as a result of the treatment + natural mortality.

${ }^{* *}$ Dropped mites+natural mortality in control+No. of mites on 100 live bees+No. of mites in 20 cells of brood.

\section{RESULTS AND DISCUSSION}

\section{1- Mint oil:}

Table (1) showed that the efficacy rate ranged from 40 to $88.89 \%$ with an average of $64.75 \%$ on H.L.H.. This rate was higher than that of L.H. which ranged from 0 to $93.75 \%$ with an average of $44.76 \%$. These differences can be attributed to low levels of infestation on L.H. compared to higher ones in H.L.H.. The number of dead mites in L.H. ranged from 0 to $15 \mathrm{mites} / \mathrm{col}$ (Table 2). These are considered low numbers if compared with dead mites in H.L.H. which ranged from 3 to 9.67 mites/col. These results agree with those of Rezk and Gadelhak (1997) who used Mentha sp. in two regions in Nubarya, Egypt and found that the total cumulative numbers of fallen mites during the entire treatment were $15.67 \%$ in the first location and $14 \%$ in the second location. Also, these results agree with the findings of Allam et al. (2004) who used smoking with fresh leaves of eucalyptus and dry leaves of mentha and found that the efficacy rate ranged from 37 to $83 \%$ with an average of $57 \%$ on L.H., and from 26 to $87 \%$ with an average of $59 \%$ on C.H.. Meanwhile, number of dead mites in C.H. was higher than in L.H., where it ranged from 15.5 to 113.5 mites/col. weekly in L.H., and from 29 to 183 mites/col. weekly in C.H.. Using mint strips is more suitable and cultivation of mint around apiaries is a new method of cultural control.

\section{2-Chamomile oil:}

Table (1) showed that the efficacy rate ranged from 6.57 to $74.21 \%$ with an average of $41.08 \%$ on H.L.H. and from 54.14 to $83.62 \%$ with an average of $66.64 \%$ on L.H.. These ratios were higher than those obtained by Rezk and Gadelhak (1997) who used chamomile (Matricaria chamomilla) in two 
Table (1): Efficacy of some essential oils singly or in combination compared with mavrik against Varroa mite during September-November 2006 on two Apis mellifera stocks.

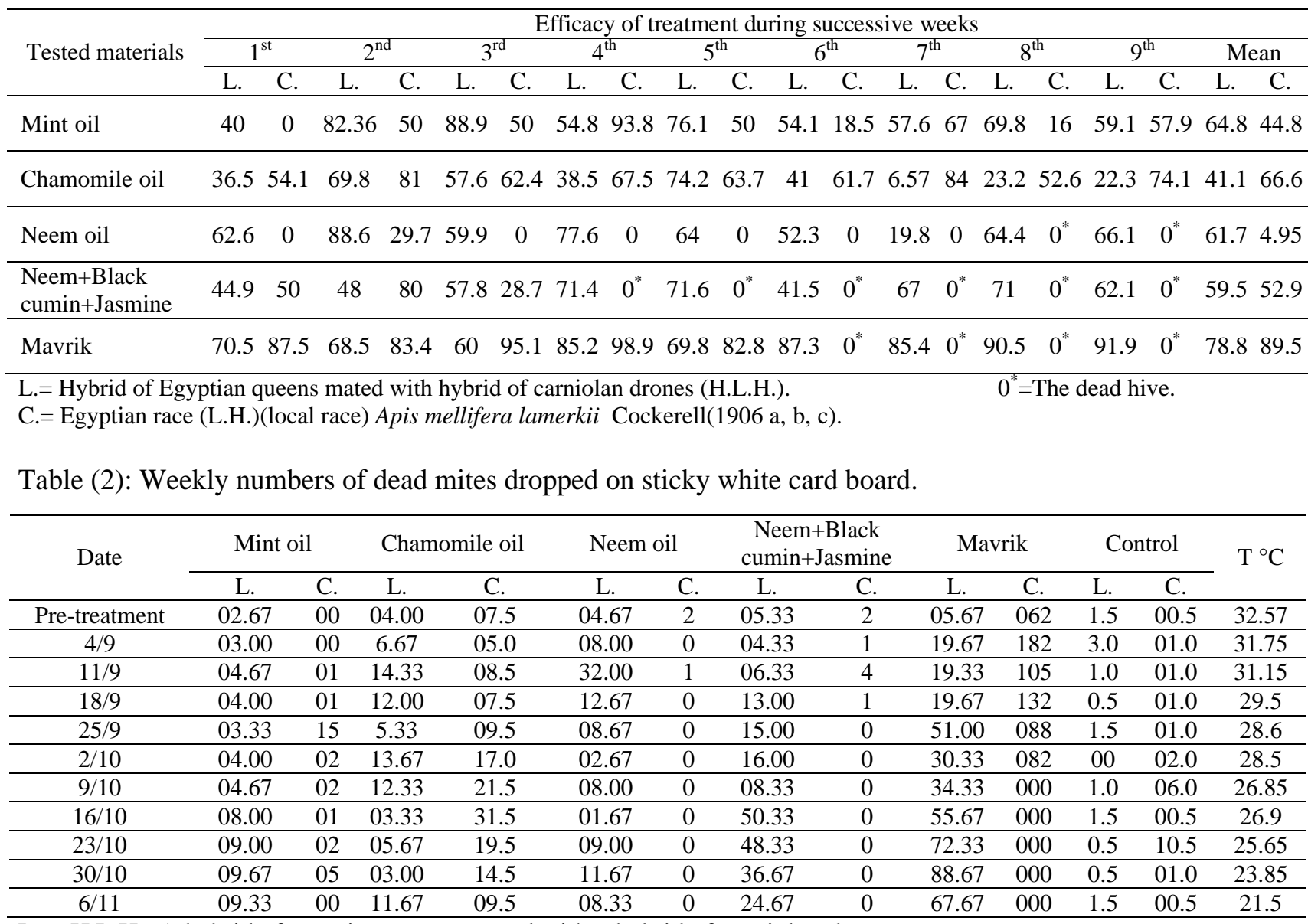

L. $=$ H.L.H. A hybrid of egyptian queens mated with a hybrid of carniolan drones.

C. $=$ H.C.H. Egyptian race (L.H.) (local race) Apis mellifera lamerkii(Cookerell, 1906 a,b,c).

region in Nubarya, Egypt and found that the total cumulative numbers of fallen mites during the entire treatment were $33.64 \%$ in the first location and $30.67 \%$ in the second location. Number of dead mites ranged from 3 to 14.33 mites/col. weekly in H.L.H., whereas ranged from 5 to $31.5 \mathrm{mites} / \mathrm{col}$. weekly in L.H. (Table 2). These results are in accordance with those of Allam et al. (2005) who recorded that the least range number of dead mites throughout the year in 2000-2001 was 3 to 76.7 $\mathrm{mites} / \mathrm{col} / \mathrm{month}$, in Sennoris region (Fayoum Governorate), due to chamomile (Matricaria chamomilla) planted greatly around bee hives.

\section{3- Neem oil:}

Table (1) showed that the efficacy rate ranged from 19.81 to $88.64 \%$ with an average of $61.7 \%$ throughout all treatments on H.L.H., and from 0 to $29.67 \%$ with an average of $4.95 \%$ in L.H.. Number of dead mites ranged from 2.67 to $12.67 \mathrm{mites} / \mathrm{col}$. weekly in H.L.H., whereas ranged from 0 to 2 mites/col. weekly in L.H. in (Table 2). These results agree with those of Allam et al. (2003) who used neem oil and found that efficacy rate ranged from
18.5 to $70.74 \%$ (average: $35.7 \%$ ), and number of dead mites ranged from 5.3 to 115.3 mites/col.weekly (average: 29.7 mites/col.).Also, Whittington et al. (2000) who used neem oil spray (5\% solution) found that it killed $90 \pm 6 \%$ of varroa mites.

\section{4- Mixture of neem, black cumin and jasmine:}

The efficacy rate ranged from 41.49 to $71.59 \%$ with an average of $59.49 \%$ on H.L.H. and from 50 to $80 \%$ with an average of $52.88 \%$ on L.H. (Table 1). Number of dead mites ranged from 4.33 to 50.33 mites/col. weekly in H.L.H., whereas ranged from 0 to 4 mites/col. in L.H. (Table 2). These results were higher than those of Allam et al. (2003) who used mixture of jasmine, neem and black cumin in 2000 and found that the efficacy rate ranged from 20.8 to $66.9 \%$ (average: $47.6 \%$ ) on H.L.H.

\section{5-Mavrik:}

Mavrik efficacy rate ranged from 59.95 to $91.87 \%$ with an average of $78.78 \%$ on H.L.H. and from 82.83 to $98.88 \%$ with an average $89.54 \%$ on L.H. (Table 1). Number of dead mites ranged from 
19.33 to 88.67 mites/col. weekly in H.L.H., whereas ranged from 0 to 182 mites/col. in L.H. (Table 2). These results are higher than those of Allam et al. (2004), who used mavrik cotton strips and found that the efficacy rate ranged from 7 to $92 \%$ with an average of $51 \%$ throughout all treatments on L.H., and from 51 to $93 \%$ with an average of $78 \%$ in C.H. and the numbers of dead mites ranged from 7 to 97.5 mites/col. weekly on L.H. and from 13 to 339 mites/col. on C.H.. Also, Kumova (2001) reported that fulvalinate (Mavrik) was $97.3 \%$ effective on $V$. jacobsoni.

\section{Overall comparison:}

The comparative results between mint oil, chamomile oil, neem oil, mixture of oils (neem, black cumin and jasmine) and mavrik in controlling varroa mites could be summarized in the following points:

- Fluctuations were noted in the efficacy rate between applications. The efficacy of all treatments during the first, second, third and fourth applications ranged from 36.51 to 88.89 . It ranged from 6.57 to $91.87 \%$ for the fifth, sixth, seventh, eighth and ninth applications in C.H. colonies. The efficacy rate of all treatments during the first, second, third and fourth application ranged from 0 to $98.88 \%$ and ranged from 0 to $90.48 \%$ on L.H. colonies.

- These fluctuations may be due to higher temperature in the first month $\left(32.75\right.$ to $\left.28.6{ }^{\circ} \mathrm{C}\right)$ than in the second month $\left(28.5\right.$ to $\left.23.65{ }^{\circ} \mathrm{C}\right)$. Temperature could act as a biotechnical treatment against varroa mites. On the other hand, there is an optimum temperature for reproduction of mites. These results are in agreement with those of Allam (1999) who reported the importance of environmental conditions in seasonal fluctuation of varroa mite.

- Neem oil is not suitable with Egyptian race.

- Using mint oil and mixture of oils is more suitable with cotton strip. These results agree with those of Allam et al. (2004) and Allam(1999) who reported that their were specifications in L.H. such as cleaning movements, shorter post capping period and its effects on durations of all biological aspects, behaviour and protein content of haemolymph. Also, supported by findings of Aumeier and Rosenkranz (2001) who evaluated hygienic behaviour of mitetolerant Africanized and susceptible Carniolan

H.L.H. = hybrid Egyptian queens (Apis mellifera lamarckii) mated with hybrid carniolan drones (A.m. carnica with no Egyptian drone, (H.C.H.). L.H= Egyptian queens Apis mellifera lamerkii (L.H.)(local race) (Cockerell,1906 a,b,c). The mated queens from this race were brought from Manfalot province. colonies in Brazil and reported hygienic reactions to mite infested brood cells. According to the previous results, the combined methods were highly recommended in integrated pest management for controlling the varroa mite together with genetic improvment of Egyptian race A. mellifera lamerckii. The cross-breeding between two geographical races resulting in hybrid vigor. In addition to using mint oil and mixture of oils with cotton strips and cultivation of aromatic plants around apiaries as a cultural control are important to obtain IPM programme to Varroa mite.

\section{Analysis of variance (ANOVA) used in the current statistical analysis}

Interaction factors (stocks and treatment) have been shown in tables 3 and 4 .

\section{Number of dead varroa mite:}

Mavrik gave the best and greatest number of dead Varroa individuals (42.21), while the smaller numbers were in the mixture of oils (20.76), chamomile oil (8.37), neem oil (9.76) and mint oil (5.07) and the control (1.14). This was for Egyptian race (a1). On the other hand, there was a decrease in the number of Varroa mite of hybrid Egyptian carniolan (a2) in a comparison with a1 because the number of days of sealed worker brood was low in a2 being 12 days. Therefore, it is not allowed to repeat life cycle. These results agree with those of Allam,(1999) who reported that the number of dead

Table (3): A comparison between stocks and treatments.

\begin{tabular}{lcccccc}
\hline \multirow{2}{*}{ Treatment } & \multicolumn{3}{c}{ Stock a1 } & \multicolumn{3}{c}{ Stock a2 } \\
\cline { 2 - 8 } & $\mathrm{M}$ & $\mathrm{B}$ & $\mathrm{W}$ & $\mathrm{M}$ & $\mathrm{B}$ & $\mathrm{W}$ \\
\hline Mint oil & 05.07 & 1.32 & 1.00 & 02.64 & 0.17 & 0.040 \\
\hline Chmomile oil & 08.37 & 9.99 & 2.45 & 13.77 & 1.01 & 0.590 \\
\hline Neem oil & 09.76 & 2.16 & 1.95 & 00.28 & 0.05 & 0.110 \\
\hline Mixture of oils & 20.76 & 6.67 & 4.82 & 00.73 & 0.48 & 0.001 \\
\hline Mavrik & 42.21 & 5.30 & 2.78 & 59.18 & 1.18 & 1.260 \\
\hline Control & 01.14 & 0.45 & 0.29 & 02.27 & 0.96 & 0.720 \\
\hline a2: Hybrid Egyptian carniolan. & B: No. of mites on 100 bees. \\
a1: Egyptian race. & M: No. of dead mites on the cardboard. \\
W: No. of mites on 20 pupae (workers).
\end{tabular}

Table (4): Statistical analysis of interaction between several factors affecting this experiment.

\begin{tabular}{lccc}
\hline Factors & $\begin{array}{c}\text { No. of dead mites } \\
\text { on cardboard }\end{array}$ & $\begin{array}{c}\text { No. of mites } \\
\text { on worker }\end{array}$ & $\begin{array}{c}\text { No. of mites on } \\
\text { worker brood }\end{array}$ \\
\hline A & $*$ & $*$ & $*$ \\
\hline B & $*$ & $*$ & $*$ \\
\hline C & $*$ & $*$ & $*$ \\
\hline AXC & $*$ & $*$ & $*$ \\
\hline BXC & $*$ & $*$ & $*$ \\
A = Stock (Race) & $*$ & $*$ & $*$ B Date \\
C $=$ Treatment & & $*$ Significantly
\end{tabular}


$V$. destructor individuals on white cardboard were greatly lower in local Egyptian race (L.E.R.) ranging from 0.001 to $29 \mathrm{mites} / \mathrm{colony} / \mathrm{week}$. In the hybrid Egyptian carniolan (H.L.H.) it ranged from 0.33 to 26.67 mites/colony/week. Allam et al. (2004) also found the lowest numbers of dead mites on white cardboard in L.E.R. and H.L.H. and this is in agreement with those of Abd EL-Wahab (1996) who noticed low number in dead mite on L.E.R. in comparison with other races and their hybrids. Also, there is an increase of cleaning movements and aggressive behavior which lead to decrease in population varroa. There were significant differences between treatments in a1 except for neem oil and chamomile oil, whereas no significant differences between all treatments in a2occurred (Table 3). The area of sealed worker brood $\left(\right.$ inch $\left.^{2}\right)$ in a1 was less than 2 in neem oil, mixture and mavrik.

\section{Number of Varroa mite on alive bees:}

The best time for the two stocks was the seventh week (October). September was the best time for control of a2 and October for a1 in a comparison with (Allam et al. 1994) who reported that the best time for the control of hybrid carniolan bees was the middle of August. The differences in the best times and the delay to the middle of September and October referred to stocks tolerance to infestation. As a result, these decrease the cost of economic control, time of control and the effort. Also, the delay of control to September gives a chance to finish honey flow.

Table (3) shows that in a1, the best oil for controlling Varroa mite on alive honeybee is chamomile (9.99), mixture of oils (6.67), mavrik (5.3), neem oil (2.16) while the least oil is mint oil (1.32). There are significant differences between treatments except between mixture of oils and mavrik. On the other hand, for a2, there are no significant differences between mint oil, neem oil and mixture of oils. Also, there are no significant differences between chamomile oil, mavrik and control. This indicates that mint oil, neem oil and mixture of oils have a great effect on increase of excitation and aggressive behavior and this leads to decrease the number of varroa mite on alive honeybee and increase the cleaning movements. These results agree with those of Zakaria \& Sally (2007) who reported that there was relationship between formic acid and black cumin oil treatments and grooming behavior. On contrast, chamomile oil, mavrik and control have not the same effect as mint oil, neem oil and mixture of oils. This shows that they have not any effect on cleaning movements.

\section{Number of Varroa mite on worker brood:}

Table (4) shows that in stock a1, there are significant differences between all treatments except chamomile oil and mavrik. In stock a2, there are no significant differences between chamomile oil, neem oil and control and also between mint oil and mixture of oils. As a result, there is no effectiveness when these oils used alone and also to decrease the entrance of Varroa mite to cells. Therefore, these oils have no effect on decrease of population of Varroa mite to complete its life cycle. In general, mixture of oils and mavrik are the most effective treatments to decrease the number of Varroa mite on worker brood. Also, there are significant differences between mixture of oils and mavrik and all treatments.

Chamomile oil has a similar effect as the insecticide mavrik, but oils (mixture of oils) are better than the insecticide mavrik. These results agree with Allam et al. (2003) who used mixture of jasmine, neem and black cumin oils in Varroa control. Mint oil has the least effect to decrease the number of Varroa mite on worker brood being similar to the control. This result allows us to recommend mint oil and chamomile oil to be used with mixtures of oils, but not alone. From the previous results we can add to IPM programme these new trends for the control of Varroa mite:

1- Cultivation of mint or chamomile around apiaries (a new cultural control).

2- Genetic improvement by using hybrid queens between A. mellifera carnica (drones) and A. mellifera lamerkii (virgins), could be an effective and reliable method for Varroa destructor, control.

3- Application of mixtures of essential oils on cotton strips.

\section{REFERENCES}

Abd El-Fattah, M. A., Nour, M. E. and El-Shemy, A. A. M. 1991. Efficacy of chemical compounds to control varroa mite (Varroa jacobsoni Oud.) in honeybee colonies in Egypt. Egypt. J. Appl.sci., 6(12): 139-152.

Abd El-Wahab, T. E. 1996. Relation between Varroa mites infestation and biological activities of honeybee races and hybrids in Egypt. M.Sc. Thesis, Fac. of Agric., Cairo Univ., Egypt.

Abo-Shady, M. 1939. Principles of bees. A book published by Association of honeybee in Egypt.

Allam, S. F. M. 1994. Ecological, Biological and control studies on Varroa jacobsoni a parasitic mite of honey bees in Egypt. M.S.C., faculty of Agriculture, Cairo University, Giza, Egypt.. 
Allam, S. F. M. 1999. Studies on honeybee parasites in Egypt. Ph.D. thesis, Fac. of Agric., Cairo Univ., Egypt, 199 pp.

Allam, S. F. M. Hassan, M. F., Risk, M. A. and Zaki, A. Y. 2003. Utilization of essential oils and chemical substances alone or in combination against varroa mite (Varroa destructor), a parasite of honeybee. Insect pathogens and insect parastic Nematodes. IOBC wprs Bulletin 26(1): 273-274.

Allam, S. F. M., Hassan, M. F., Rizk, M. A. and Zaki, A. Y. 2004. Comparison among certain natural products, formic acid and mavrik against varroa mite, Varroa destructor, a parasite of honeybee on two stocks of Apis mellifera in Egypt. Minufiya J. Agric. Res. 29 (6): 1387-1395.

Allam, S. F. M., Hassan, M. F., Rizk, M. A. and Zaki, A. Y. 2005. Seasonal fluctuations infestation levels of Varroa destructor on honeybee colonies in middle Egypt. Minufiya J. Agric. Res. 30(2):689-708.

Anderson, D. L. and Trueman, J. W. H. 2000. Varroa jacobsoni (Acari:varroidae) is more than one species. Exp. and Appl. Acarology, 24: $165-189$.

Aumeier, P.and Rosenkran Z. 2001. Scent or movement of Varroa destructor mites does not elicit hygienic behaviour by Africanized and carniolan honeybee. Apidologie 32(3): 253-263.

Bienefeld, K. 1996.Factors affecting duration of the post-capping period in brood of the honeybee(Apis mellifera carnica). J. Apic. Res., 35(1): 11-17.

Cockerell, T. D. A. 1906a. Description and records of bees. -VII. Annals and Magazine of Natural history (7) 17: 23-29.

Cockerell, T. D. A. 1906b. Description and records of bees. -XI. Annals and Magazine of Natural history (7) 17: 527-539.

Cockerell, T. D. A. 1906c. Description and records of bees. -XII. Annals and Magazine of Natural history (18) 17: 69-75.

De Jong, D., Morse R. A. and Eickwort, G. C. 1982. Mite pests honeybees. Ann. Rev. Entomol. 27: $229-252$.

El-Shemy, A. A. M. 1997. Potential methods of controlling Varroa mite (Varroa jacobsoni Oud.) without chemicals. J. Agri. Sci., Mansoura Univ.,
22 (12):4643-4653.

Fathy, H. M. and Fouly, A. H. 1993. The acaricidal effect of camphor oil on Varroa jacobsoni infesting honeybee in Egypt. J. Agric Sci., Mansoura Univ., 18 (12):3698-3705.

Girodan, G. and Leporati, M. 1989. Field trials against Varroa jacobsoni with Apitol in "present status of Varratosis in Europe and progress in Varroa Control". Edited by Cavallorar. pro. of Meeting of the EX Exterts Group/udine Italy, 28-30 Nov.1988.

Guzman, E. N.; Sanchez, A.; Page, R. E., Jr. and Garcia, T. 1996. Susceptibility of European and Africanized honeybees (Apis mellifera L.) and their hybrids to Varroa jacobsoni Oud. Apidologie, 27: 93-103.

Hoppe, H.; Pritter, W. and Elizabeth, W. C. 1989. The control of parasitic mites: Varroa jacobsoni, Acarapis woodi and Tropilaelaps clareae with formic acid Amer. bee J., 129:739-742.

Ifantidis, M. D. 1987. Varroa jacobsoni Oud. Apects of biology and propects of control. Aplicollore Moderno 1987, 78 (4): 135-145.

Kumova, U. 2001. The investigation on the effects of some chemicals used to control Varroa jacobsoni in Turkey. Turk-Veterinerlik-VeHayvancilik-Dergisi. 25 (4): 597-602.

Rezk, H. A. and Gadelhak, G. G. 1997. Impact of four plant oil extracts on the control of the parasitic mite, Varroa jacobsoni oud. (Acari: Mesostigmata). Alex. J. Agric. Research. 42 (3) $105-113$.

Whittington, R.,Winston, M. L., Melathopoulos, A. P. and Higo, H. A. 2000. Evaluation of the botanical oils neem, thymol and canola sprayed to control Varroa jacobsoni Oud. (Acari: varroidae) and Acarapis woodi (Acari: Tarsonemidae) in colonies of honey bees (Apis mellifera L., Hymenoptera: Apidae). Amer. Bee. J. 140 (7): 567-572.

Wienands, A. 1988. The varroa mite has spread over most the world. Amer. Bee. J., 128 (5): 358 359.

Zakaria, M. E. and Allam, Sally F. 2007. Effect of some aromatic oils and chemical acaricides on the mechanical defense behavior of honey bees against Varroa invasion and relationship with sensilla responsiveness. Journal of Applied Sciences Research, 3(7): 653-661. 